\title{
Treatment of Textile Wastewater by Coagulation Precipitation Method
}

\author{
M. A. Sabur*, A. A. Khan, S. Safiullah \\ Department of Chemistry, Jahangirnagar University, Bangladesh
}

Received 27 May 2012, accepted in final revised form 16 August 2012

\begin{abstract}
Treatment of textile effluent, collected from Sattar Textile located at Chandra under Gazipur district, Bangladesh was carried out by chemical coagulation and precipitation method. The highly alkaline $(\mathrm{pH}=12.0)$ reddish orange colored effluent was characterized by chemical oxygen demand (COD) $1638 \mathrm{mg} \mathrm{O}_{2} / \mathrm{L}$; total suspended solids (TSS) $9.76 \mathrm{~g} / \mathrm{L}$; total dissolved solids (TDS) $6.62 \mathrm{~g} / \mathrm{L}$ and turbidly $31.24 \mathrm{FTU}$. In the present study, polyaluminium chloride (PAC) and SAFI (described in the results and discussions part) solutions were used as coagulants both individually and as their mixture at various ratios. As coagulation precipitation is highly $\mathrm{pH}$ sensitive, influence of $\mathrm{pH}$ was noted in each case. It was seen that the combined effect of both the coagulants is more effective than the individual effect of coagulants at a particular proportion at $\mathrm{pH} 6$ for the removal of pollutional load from the effluent. The minimum dosages for the coagulants were worked out also from the initial beaker experiments. Finally, the effluent obtained from the large scale treatment was characterized for some effluent quality parameters and 90.17, 74.09 and 93.47\% removal COD, TDS and turbidity were observed, respectively.
\end{abstract}

Keywords: Textile effluent; Coagulation precipitation; Chemical oxygen demand; Total Suspended solids; Dissolved solids.

(C) 2012 JSR Publications. ISSN: 2070-0237 (Print); 2070-0245 (Online). All rights reserved.

doi: http://dx.doi.org/10.3329/jsr.v4i3.10777 J. Sci. Res. 4 (3), 623-633 (2012)

\section{Introduction}

Bangladesh is a developing country and it has been seen rapid industrialization during the last one decade in various sectors. All these industries use large variety of chemicals in considerable quantities. As of now most of the industries are concentrated in or near the three major metropolitan cities namely Dhaka, Chittagong and Khulna as shown in the map (Fig. 1). Amongst the various industrial sectors, pollution by textile and dyeing, tanneries and pharmaceuticals are causing serious damage and thereby engendering public concern [1].

Textile effluents are usually extremely heterogeneous in composition with a large extent of toxic and sometimes unmanageable objects coming from dyeing and finishing processes. These processes involve the input of a wide range of chemicals and dyestuffs,

\footnotetext{
* Corresponding author: sabur227@yahoo.com
} 
which are generally organic compounds with complex structures [2]. Because all of them are not contained in the final product, ends up as wastewater, which needs to be treated before its final discharge [3]. The effluents are generally characterized by strong coloration, high load of suspended solids, COD, BOD and high conductivity [4]. The removal of color from textile and dyestuff manufacturing industrial wastewaters is a major environmental concern. In addition, only $47 \%$ of 87 of dyestuffs are biodegradable [5] and the rest of them remain in the environment.

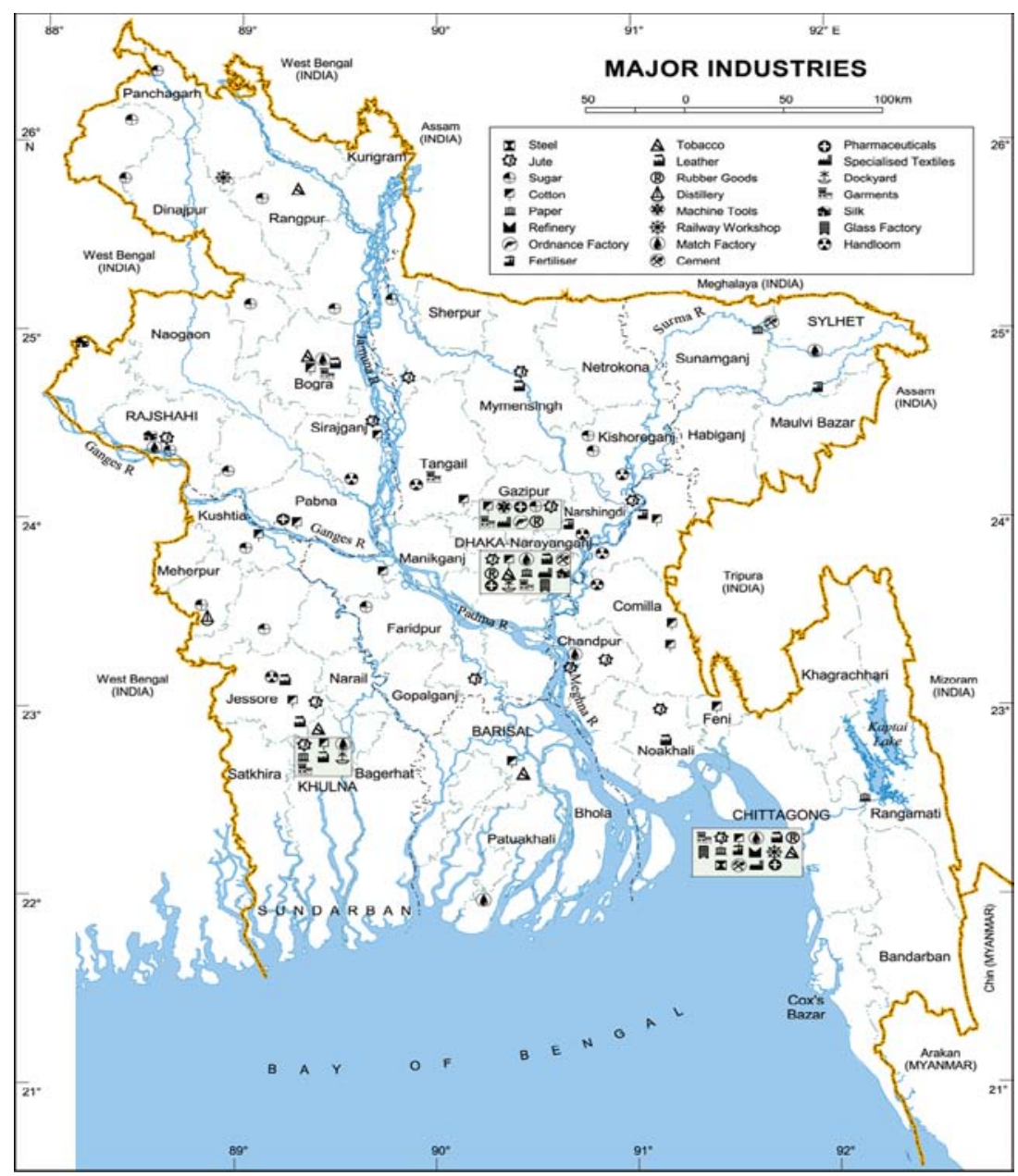

Fig. 1. Map of Bangladesh locating the major industrial zones.

For the dyeing of cellulose and cotton fibers, wide gradations of reactive dyes are used. However, these dyes are highly soluble in water and also have low levels of fixing to fibers, most of their initial concentrations being lost to the effluent. Many treatment processes for textile effluents have been studied. The contaminating substances present 
in a textile effluent cannot be removed by simple physical separation in many cases [68]. The physicochemical processes applied to clarify effluents are based on the destabilization of the colloids by coagulation-flocculation, and phase separation through sedimentation or floatation [9]. Biological treatment by activated sludge process can effectively reduce COD from wastewater but not much successful in the removal of color. According to Solmaz et al. [9], chemical oxidation with ozone, or a combination of UV radiation, ozone and $\mathrm{H}_{2} \mathrm{O}_{2}$, are of great interest, but the methods are not cost effective [9] and can be applied in combination with other conventional treatments [10 13]. Effluent of some industries can also be treated by photo oxidation on some photoactive substances such as titanium dioxide but the treatment system requires a rigorous source of UV light or should be carried out under intensive sunlight; where the second way is highly season dependent [14].

Coagulation-flocculation is a commonly used physicochemical treatment procedure that can be employed in textile wastewater treatment plants to decolorize effluent and also to reduce the total load of pollutants. Complete decolorization of wastewater can be achieved through this process [15]. The main advantage of the coagulation-flocculation method is that the textile wastewater can be decolorized through the removal of dye molecules from the effluents, and not by partial decomposition of dyes, which could produce potentially harmful and toxic aromatic compounds [16]. The efficiency of this method depends on the characteristics of raw wastewater, $\mathrm{pH}$ and temperature of the solution, the type and dosage of coagulants, and the intensity and duration of mixing [17 - 18].

Bangladesh is a developing country and it has been getting industrialized for previous two decades. Of the industries, a very few are using Effluent Treatment Plan (ETP) based on biological process. The process requires huge amount of capitals for its initial set up along with foreign technology. As a result, almost all the industries are releasing their effluent to the nearest water bodies as well as to the environment without considering any mitigative measures and the state of our environment are declining gradually with industrialization. So, considering the present needs of Bangladesh in this sector, this research was undertaken with the objective for the treatment of textile effluent by chemical coagulation and precipitation method in a cost effective way.

\section{Experimental}

Around 100.0 L effluent sample was collected (in fresh plastic containers previously washed with dilute $\mathrm{HNO}_{3}$ ) from the Sattar Textile, Chandra, Gazipur when the industry was in operational condition. A few $\mathrm{mL}$ of conc. $\mathrm{HNO}_{3}$ was added to the effluent to prevent the growth of microbial bacteria and was sealed to prevent air oxidation. The raw effluent was then analyzed for some physicochemical parameters such as $\mathrm{pH}$, COD, TSS, TDS, turbidity etc. within a week of sample collection.

Initially batch experiments were carried out with $200.0 \mathrm{~mL}$ effluent in five $500 \mathrm{~mL}$ beakers and $\mathrm{pH}$ of the systems were altered to 7.0 by the gradual addition of $25 \%$ acetic acid. After the adjustment of pH, 1.0, 2.0, 3.0, 4.0 and $5.0 \mathrm{~mL}$ of PAC slurry (prepared by mixing solid PAC with water in a specific ratio) was added to all the beakers successively using $5.0 \mathrm{~mL}$ graduated pipette with continuous stirring by a glass rod. 


\section{6}

While adding, quick coagulation and sedimentation was noticed. Within half an hour, the coagulation and sedimentation was seen to be completed. However, the whole system was allowed to stand for around six hours for the completion of the process. The treated effluent, the clear upper part, was decanted carefully for the analysis of some effluent quality parameters.

To observe the influence of $\mathrm{pH}$ on the efficiency of the PAC as coagulant for this particular effluent, four $500 \mathrm{~mL}$ beakers with $200.0 \mathrm{~mL}$ effluent in each were taken and $\mathrm{pH}$ was altered to $6.0,7.0,8.0$ and 9.0 in four beakers respectively by carefully adding $25 \%$ acetic acid. Minimum amount of PAC slurry as obtained from the previous experiment was added to each of the beakers. Both the above procedures were repeated for SAFI solution as well as for the combined solution of both the coagulants.

UV spectra were collected at different stages in our study by using UV-1601PC, SHIMADZU spectrophotometer. $\mathrm{pH}$ was measured with a Schott Gerate (CG-818 model) $\mathrm{pH}$ meter. TSS was determined gravimetrically by filtering a well-mixed sample through a weighed standard glass-fiber filter and the residue retained on the filter was dried to a constant weight at 103 to $105^{\circ} \mathrm{C}$. For TDS measurement, the filtrate obtained from the TSS determination was evaporated taking in a weighed dish to dryness and then dried at $180^{\circ} \mathrm{C}$ up to a constant weight. The increase in dish weight represents the total dissolved solids. COD was measured by conventional open reflux method. All the experiments were carried out in the Department of Chemistry, Jahangirnagar University.

\section{Results and Discussions}

The physicochemical characteristics of the collected raw effluent were analyzed and the results are presented in the following Table 1.

Table 1. Characteristics of the raw effluent collected from Sattar Textile.

\begin{tabular}{ll}
\hline Parameters & Value \\
\hline Color & Reddish orange \\
$\mathrm{pH}$ & 12.0 \\
Total suspended solids (TSS) in g/L & 9.76 \\
Total dissolve solid s(TDS) in g/L & 6.62 \\
Turbidity in FTU & 31.24 \\
Chemical oxygen demand (COD) in $\mathrm{mg} \mathrm{O}_{2} / \mathrm{L}$ & 1638 \\
\hline
\end{tabular}

\subsection{Treatment with PAC}

The treatment was carried out using the coagulants PAC and SAFI solution individually where the PAC is a commonly used coagulant for the treatment of industrial wastewater 
$[19,20]$. The combined effects of both the mentioned coagulants were investigated also. Initially, dosages were optimized for each of the coagulants initially keeping the $\mathrm{pH}$ of the effluent at 7.0 and then the effect of $\mathrm{pH}$ was observed on coagulation process. The same procedures were repeated with the combined solution of the coagulants. UV spectrophotometric analysis, can be used for the comparative study of water and wastewater quality [21], was undertaken herein to monitor the progress of the treatment.

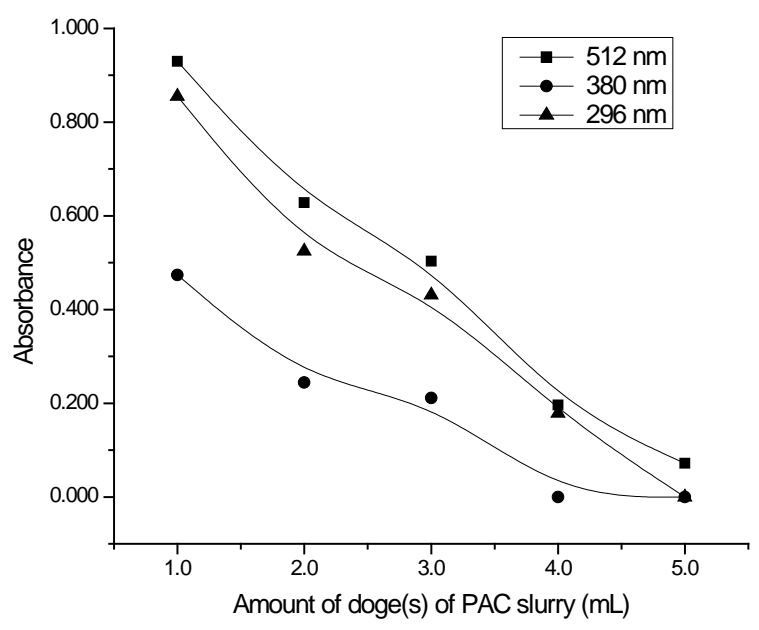

Fig. 2. Variation of absorbance with different dosages of PAC at pH 7.

For the raw effluent, the major absorptions were noticed mainly at three wavelengths; 512, 380 and $296 \mathrm{~nm}$. From Fig. 2, it is found that, the value of absorbance decreases with increasing the amount of PAC slurry. We observed best treatment with a dosage $5.0 \mathrm{~mL}$ of PAC solution per $200 \mathrm{~mL}$ effluent as explained by the lowest absorbance value 0.072 at $512 \mathrm{~nm}$ where absorbance of the raw effluent was 0.930 . The decreasing trend of absorbance at this wavelength was reflected noticeably during the course of our study as the wavelength at $512 \mathrm{~nm}$ falls within the visible region. Besides this, the treated sample was not seen to absorb at other wavelengths, 380 and $296 \mathrm{~nm}$.

The $\mathrm{pH}$ of the system affects surface charge of the coagulants and hence the stabilization of the suspension [22, 23]. Wastewater treatments based on coagulation/flocculation were studied by many researchers and $\mathrm{pH}$ was found to be maintained with a special care [20, 24-26]. In this regard, the physicochemical parameters such as COD, TDS and turbidity of the treated effluent were also determined 
within a range of $\mathrm{pH}$ from 6.0 to 9.0. The variations are presented by the figure 3 and the lowest values for the above mentioned parameters were obtained when the treatment was carried out at $\mathrm{pH}$ 6. That is, PAC performs well as coagulant for the treatment of the effluent at this particular $\mathrm{pH}$.

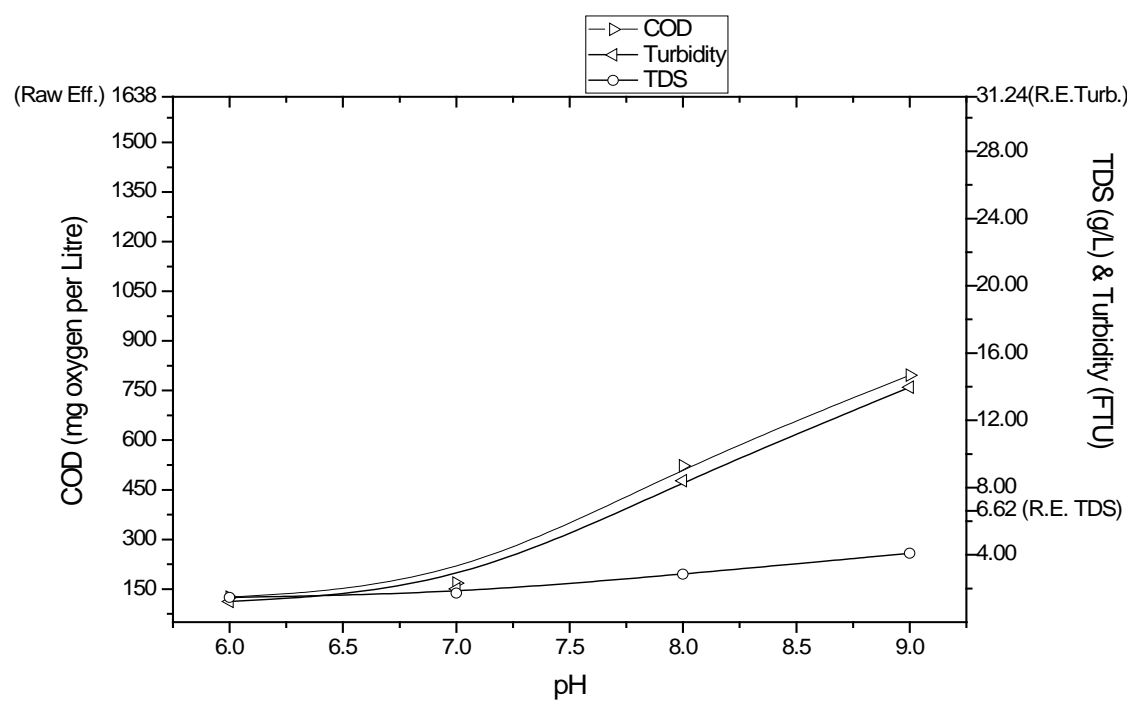

Fig. 3. Influence of $\mathrm{pH}$ on the coagulation using PAC in terms of COD, TDS and Turbidity.

\section{2 . Treatment with SAFI solution}

From the eye observation as well as from the UV-spectrophotometric analyses, the best treated effluent by SAFI solution was studied further for the other effluent quality parameters mentioned earlier. In this case, the main absorption peaks are seen at wavelengths 512, 380 and $296 \mathrm{~nm}$ for five different dosages of the SAFI solution when $\mathrm{pH}$ was maintained at 7.0. From the above five treatment systems using SAFI solution, it is seen that $4.0 \mathrm{~mL}$ of $10 \%$ SAFI solution is sufficient to treat $200.0 \mathrm{~mL}$ of the effluent for the removal of UV active chemicals from the effluent and $3.0 \mathrm{~mL}$ SAFI solution of the specified concentration may also be enough (Fig. 4) in this regard. So, further study for the other effluent quality parameters were carried out to observe the influence of $\mathrm{pH}$ on the coagulation of the mentioned experimental scheme.

The SAFI solution is actually a mixture of the salts of iron(II), Mn(II) and aluminium(III) at a particular proportion and in the effluent it produces the corresponding hydroxides and act as a coagulant. The UV-Visible spectra of the treated samples using $3.0 \mathrm{~mL} 10 \%$ SAFI solutions at various $\mathrm{pH}$ 6.0, 7.0, 8.0 and 9.0 were recorded and the major absorptions were found at the wavelengths 512, 380 and in 296 $\mathrm{nm}$. The absorbance values were found to increase with the rise of $\mathrm{pH}$ and the same 
trend was noticed for the values of COD, TDS and turbidity as well. The SAFI solution works suitably within the $\mathrm{pH}$ range 6.0 to 7.0 (Fig. 5) for this particular effluent.

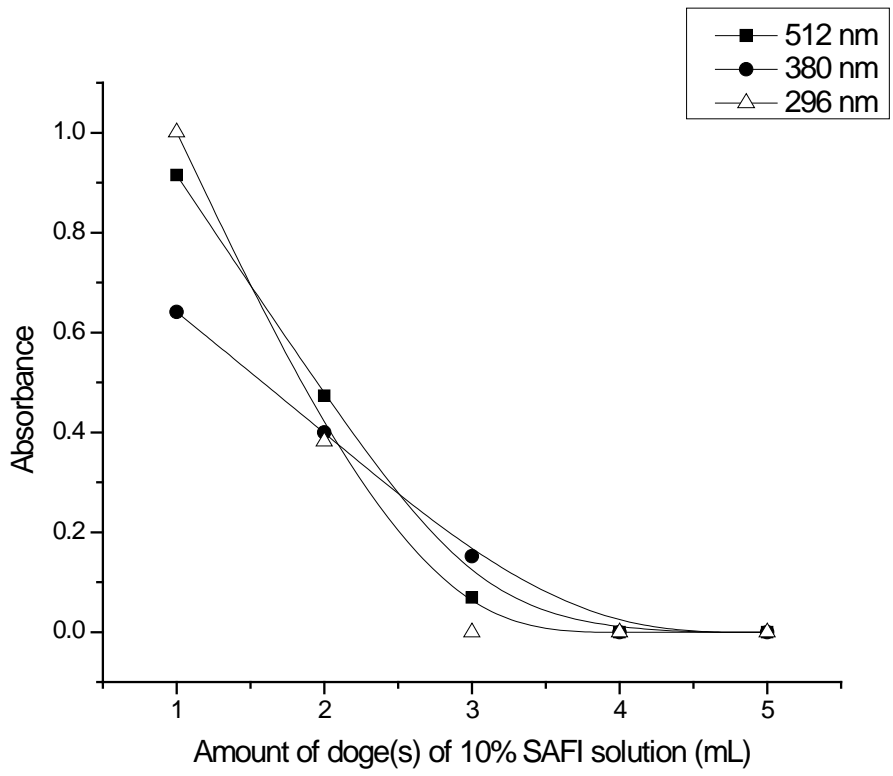

Fig. 4. Variation of absorbance with different dosages of SAFI solution at pH 7.

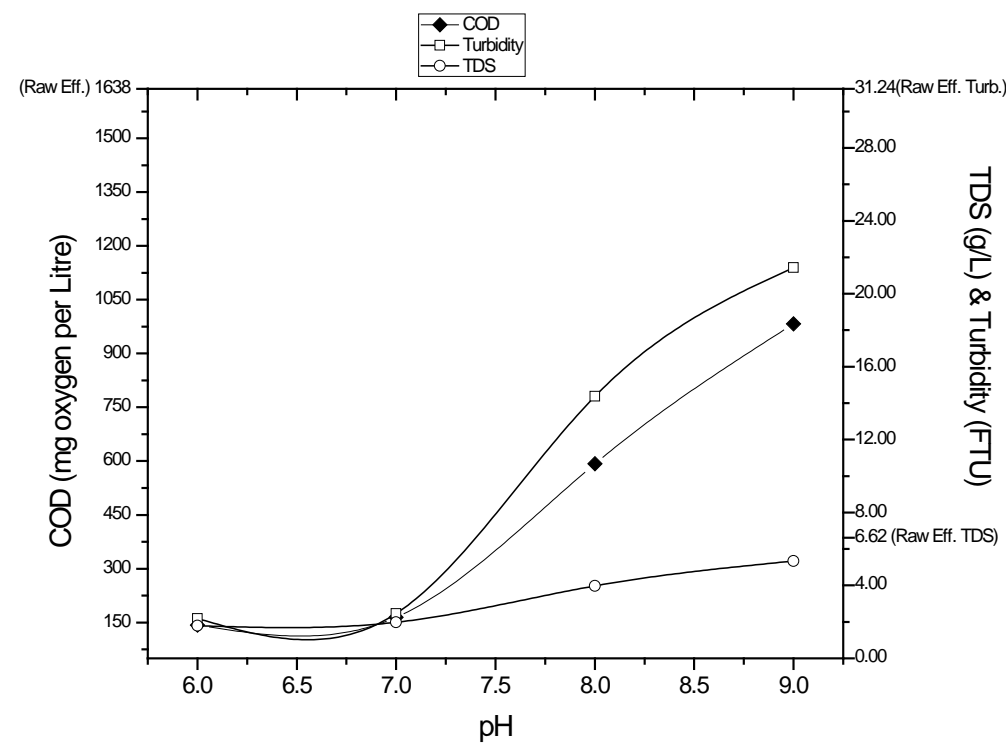

Fig. 5. Treatment of the effluent in terms of COD, TDS and Turbidity using SAFI solution as a function of $\mathrm{pH}$. 


\subsection{Effluent treatment by the mixture of both the coagulants}

Treatments with the mixture of the coagulants were studied also so as to see the combined effect of the coagulants for the removal of organic and inorganic pollutants from the effluent. From the individual treatment by 10\% SAFI solution and PAC slurry, it is found that, both the coagulants perform well at $\mathrm{pH} 6.0$ for the removal of dissolved organic and inorganic compounds from the effluent of the Sattar Textile. In this regard, mixtures of both the coagulants at various ratios were added to each of the $200.0 \mathrm{~mL}$ of the effluent separately followed by the adjustment of $\mathrm{pH}$ at 6.0. Total of eight type combinations of the coagulants were prepared and the compositions of various combinations are given in Table 2.

Table 2. Various types of mixture of coagulants used for the treatment.

\begin{tabular}{ccc}
\hline $\begin{array}{c}\text { Mixture } \\
\text { Type }\end{array}$ & $\begin{array}{c}\text { Amount of } 10 \% \text { SAFI } \\
\text { solution }(\mathrm{mL})\end{array}$ & $\begin{array}{c}\text { Amount of PAC slurry } \\
(\mathrm{mL})\end{array}$ \\
\hline 1 & 1.0 & 1.0 \\
2 & 1.0 & 2.0 \\
3 & 1.0 & 3.0 \\
4 & 1.0 & 4.0 \\
5 & 1.0 & 5.0 \\
6 & 2.0 & 1.0 \\
7 & 2.0 & 2.0 \\
8 & 3.0 & 1.0 \\
\hline
\end{tabular}

From the analyses of UV spectra for both the untreated and treated effluent, it is seen that the effluent becomes almost free from UV active agents by the mixture type 4 as well as by the type 6 (spectra have not been given here). For better understanding, other effluent quality parameters such as COD, TDS and turbidity were determined also for each of the eight systems and they are seen to vary for the treated samples obtained from each of the eight combinations of the coagulants (Fig. 6). From the analytical results, it is evident that the lowest values for the above mentioned three effluent quality parameters were obtained for the combination type 4 . 


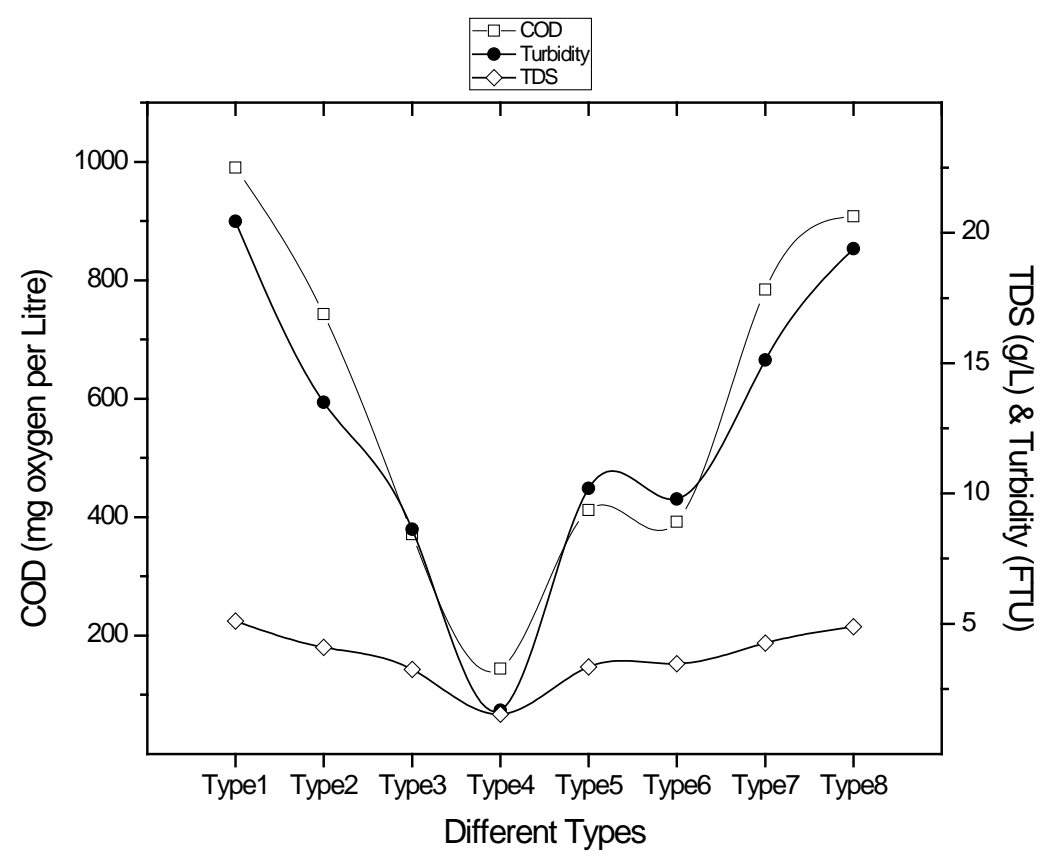

Fig. 6. Change of COD, TDS and turbidity with various combinations of the coagulants.

\subsection{Large scale treatment with the mixture of the coagulants}

UV-Visible spectra for both the untreated effluent and the treated effluent from the large scale treatment were recorded; the same analytical tool was used by Vaillant et. al. for water and wastewater quality monitoring [27]. For the untreated effluent the absorbance values were 1.274, 1.492 and 1.761 at wavelengths 512, 380 and $296 \mathrm{~nm}$, respectively. After the treatment we notice to reduce the values to $0.036,0.021$ and 0.179 in the same order. The COD is the measure of the pollutional strength of wastewater. The initial value of COD of Sattar Textile was1638 $\mathrm{mg} \mathrm{\textrm {O } _ { 2 }} / \mathrm{L}$ and after small and large scale

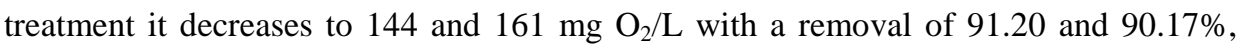
respectively. The decreasing trend of COD value indicates that significant amounts of organic waste as well as inorganic species got deposited with the coagulants and most of them were removed from the system as sludge. TDS and turbidity of the treated effluent were also seen to decrease in an appreciable amount through both the small and large scale treatment. The particles and compounds responsible for TDS were removed 76.89 (small scale) and $74.09 \%$ (large scale) whereas turbidity values were seen to decrease 94.62 and $93.47 \%$ in the small and large scale treatment, respectively in our study. 


\section{Concluding Remarks}

The treatment of textile effluent based on chemical coagulation and precipitation was seen to remove pollutants from the wasewater effectively. So ETP based on this process can be employed in the textile and dyeing industries to reduce the pollution occuring to our environment. The sludge obtained from this treatment procecss can be used as a component of slow release organic fertilizer as it has soil conditioning capability. Heavy metals bounded to the organic compounds present in sludge may act as a rich nutrient source. However, extensive use of sludge in fertilizer on soil may be a matter of concern for the risk of heavy metal contamination.

\section{References}

1. S. Safiullah, Theme Lecture, Chemical Congress, Bangladesh Chemical Society, December 10 (2010).

2. A. Al-Kdasi, A. Idris, K. Saed, and C. T. Guan, Global Nest: the Int. J. 6 (3), 222 (2004).

3. A. Cerqueira, C. Russo, and M. R. C. Marques, Brazilian J. of Chem. Eng. 26 (4), 659 (2009).

4. M. Koch, A. Yediler, D. Lienert, G. Insel, and A. Kettrup, Chemosphere. 46 (1), 109 (2002). http://dx.doi.org/10.1016/S0045-6535(01)00102-3

5. U. Pagga and D. Brown, Chemosphere 15 (4), 479 (1986). http://dx.doi.org/10.1016/0045-6535(86) 90542-4

6. M. Dogan and M. Alkan, Chemosphere, 50 (4), 517 (2003). http://dx.doi.org/10.1016/S0045-6535(02)00629-X

7. T. Kim, C. Park, E. Shin, and S. Kim, Desalination 161 (1), 49 (2004). http://dx.doi.org/10.1016/S0011-9164(04)90039-2

8. S. Senthillkumaar, P. Kalaamani, and C.V. Subburaam, J. Hazard. Mater. B 136, 800 (2006). http://dx.doi.org/10.1016/j.jhazmat.2006.01.045

9. S. K. A. Solmaz, A. Birgül, G. E. Üstün, and T. Yonar, Coloration Technol. 122, 102 (2006). http://dx.doi.org/10.1111/j.1478-4408.2006.00016.x

10. S. Barreto-Damas, M. I. Iborra-Clar, A. Bes-Piá, M. I. Alcaina-Miranda and J. Iborra-Clar, Desalination 182, 267 (2005). http://dx.doi.org/10.1016/j.desal.2005.04.017

11. M. Kabsch-Korbutowicz, Desalination 194 (1-3), 232 (2006). http://dx.doi.org/10.1016/j.desal.2005.09.031

12. F. Harrelkas, A. Azizi, A. Yaacoubi, A. Benhammou, and M.N. Pons, Desalination 235 (1-3), 330 (2009). http://dx.doi.org/10.1016/j.desal.2008.02.012

13. N. V. Narayanan and M. Ganesan, J. Hazard Mater. 161 (1), 575 (2009). http://dx.doi.org/10.1016/j.jhazmat.2008.03.113

14. S. Safiullah, G. Mohammad, M. A. Sabur, and B. K. Howlader, Asian J. of Water, Environ. Pollution 9 (1), 45 (2012).

15. S. Papic, N. Koprivanac, A. L. Božic, and A. Meteš, Dyes Pigments 62, 291 (2004). http://dx.doi.org/10.1016/S0143-7208(03)00148-7

16. V. Golob, A. Vinder, and M. Simonic, Dyes Pigments 67 (2), 93 (2005). http://dx.doi.org/10.1016/j.dyepig.2004.11.003

17. M. Rossini, J. G. Garrido, and M. Galluzzo, Water Res. 33, 1817 (1999). http://dx.doi.org/10.1016/S0043-1354(98)00367-4

18. M.T. Radoiu, D. I. Martin, I. Calinescu, and H. Lovu, J. Hazard. Mater. 106B, 19 (2004).

19. B. Y. Gao, Y. B. Chu, Q. Y. Yue, B. J. Wang, and S. G. Wang, J. Environ. Management 76, 143 (2005). http://dx.doi.org/10.1016/j.jenvman.2004.12.006

20. E. Klimiuk, U. Filipkowska, and A. Korzeniowska, Polish J. Environ. Studies 8 (2), 73 (1999).

21. O. Thomas, E. Baures, and M. F. Pouet, Water Qual. Res. J. Canada 40 (1), 51 (2005). 
22. M. A. A. Hassan, T. P. Li, and Z. Z. Noor, J. Chem. Natural Res. Eng. 4 (1), 43 (2009)

23. T. Tripathy and B. R. De, J. Physical Sciences 10, 93 (2006)

24. F. R. Furlan, L. G. D. M. D. Silva, A. F. Morgado, A. A. U. D. Souza, and S. M. A. G. U. D. Souza, Res. Conservation and Recycling 54, 283 (2010). http://dx.doi.org/10.1016/j.resconrec.2009.09.001

25. G. R. N. Bidhendi, A. Torabian, H. Ehsani, and N. Razmkhah, Iran J. Environ. Health. Sci. Eng., 4 (1), 29 (2007).

26. J. Qin, M. H. Oo, K. A. Kekre, F. Knops, and P. Miller, Separation and Purification Technology 49 (3), 295 ((2006). http://dx.doi.org/10.1016/j.seppur.2005.09.016

27. S. Vaillant, M. F. Pouet, and O. Thomas, Urban Water 4 (3), 273 (2002). http://dx.doi.org/10.1016/S1462-0758(02)00019-5 